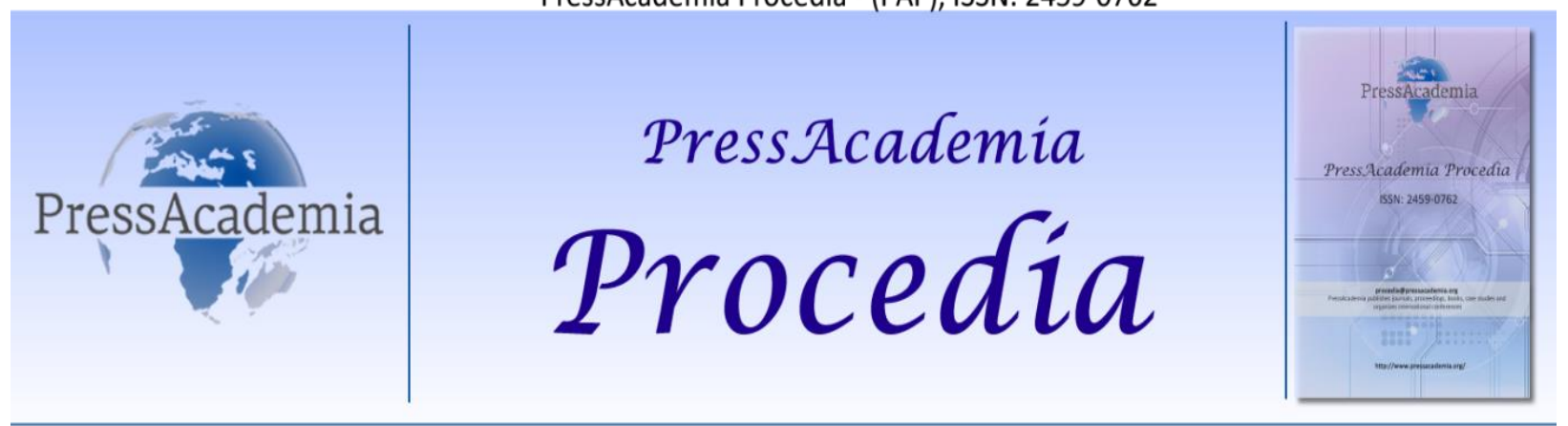

2nd World Conference on Technology, Innovation and Entrepreneurship

May 12-14, 2017, Istanbul, Turkey. Edited by Sefer Şener

\title{
TECHNOLOGY: ARE WE USING IT OR IT IS USING US?
}

\author{
DOI: 10.17261/Pressacademia.2017.533 \\ PAP-WCTIE-V.4-2017(25)-p.188-190
}

Resul Kaya ${ }^{1}$ Nermin Gurhan ${ }^{2}$

${ }^{1}$ res.kaya61@hotmail.com

nermingurhan@gmail.com

\begin{abstract}
Technological developments lead to a level of prosperity as well as to misery. Latest industrial developments also caused serious problems in the economic, social and political context. In today's world, information as well as information technology are of great significance - this will be of increased importance. Our today's source of information is based on computer technology. Wars between countries are rather made by the power of information as per weapons. While in the past, reduplication of knowledge generation took 4.000 years, today we only need 50 years for it. The accumulation of knowledge leads to new innovations so that technology is today an indispensable factor of our world. This leads to the fact, that the world is today a global village. Today, the industry is not able to meet the demand of the information society. Developments in the information technology go hand in hand with the individual context and the fields like governance, industry, economy, social policy and entertainment. The rapid change and development of technology and information caused incorrect use of technology and information as well as the facts of not being able to follow current trends and a great competitive pressure. All the above-mentioned indicators pointed to pressures and stress on people. In addition, the cultural structure and standards are negatively impacted. People and the world suffer from the incorrect use of technology and information. The rapid change of information and the access to this information caused and increased information pollution. People were not able anymore to differ between correct and incorrect information. This information pollution affected the soul and mind of people negatively.
\end{abstract}

\section{INTRODUCTION}

Technological resources lead to new methods and techniques in the learning process. This is why we have many innovations and methods in the learning environment. The technological expansion caused changes in curricula: subjects as teaching technologies, information technology and collection of information were added. Also these lessons were increased while other lessons were reduced. Although it was intended to use more technology in education, in general teacher candidates of the education faculty get educated of only limited information and methods considering technological education. Also these lessons are not connected with other disciplines. This means that teacher candidates get no information about the usability of technology. They also get no information about the scope of application and how to use it. Teacher candidates with no sensibility of using technology as a method of education are influenced negatively considering their experiences, approaching, believing and attitude. This will also influence their students negatively: Technologies in education were taught wrongly, so that the students use technology also in an ineffective way. (Çağıltay ve diğ., 2001: Öksüz ve diğ.2009 :Usta, E., Korkmaz, Ö. 2010 ).

The use of teaching material simplifies the comprehension and learning. It is an effective way of teaching. In this manner, students may achieve their goals much easier obviously. One of these teaching material is information technology. So it is possible to simplify the understanding of events and facts in the classroom. The use of visual materials are as important as the source of material as well as its preparation. (Yaşar,2004: Karamustafaoğlu vd., 2005).

It is a known fact that the learning process is a complex matter. If you want to use technological methods and materials for teaching students, the matching of various methods would be more effective. It would be a mistake to match only one method or factor with the learning process. Technological development enables experiments, sharings and other 
possibilities in teaching. On the other hand it bears the risk of reducing critical approaches. In spite of thinking, students will use made tasks and add no further information-teachers also use scripts of their colleagues. Now we fight against technological espionage/robbery, ethical violations etc.

Today, 15-years-old sutdents of OECD countries take part of the PISA (Program for International Student Assessment) test at the end of their compulsory education. With this test, we can determine how prepared the students are considering the managing of daily situations in information society. With this test we try to determine not how much the students learned by heart at school. We rather try to determine if the students are able to manage daily life by using, analysing, thinking the methods and techniques of lessons hold at school. Also their knowledge and use of science and mathematics will be determined. In this way we try to determine their ability to communicate[20].

According to the (PISA) test of the year 2009, in which 65 countries as well as Turkey took part, Turkey achieved rang 43 . in mathematics and rang 41 in reading comprehension. Students of Finland get the best results of the test. After searching for the reason of the success of Finland's students, we came to the conclusion that the following facts influenced the result:

Training of teachers,

Traditional educational path,

Prestige of teacher career,

Continuing education of teachers ( Çelen ve diğer.2011).

For being a competitive business, communication, sharing of information, using og technologies in business etc. is indispensable. Today's small-medium-sized and large companies are dependent on information technology by matters like making records, archiving, money transfers, communication. It must be known that information technologies implicate also safety problems. These problems grow continuously (malicious software-data theft - technological spying - internet piracy etc.)

Companies suffer from high damages caused by deleting of folders, damaged PCs, PC crashes and for other causes ( Acılar 2009).

Rapid technological development causes also cyber mobbing. Cyber mobbing stands for the cyber extortion, intimidation, threating, physical or psychological abuse and other actions. Cyber mobbing is made via e-mail, messages or by using pictures. For realising this kind of mobbing, web sites, blogs, chat rooms or social media are used (Arı, S. , vd. 2010: Arıcak 2011).

With the technological development, today's children are spending hours in the internet. Some of them are visiting websites with offensive contents due to unknowingness or for self-assertion. Sexual offers or sexual abuse are some of the consequences. According to the report of 'World Tracker', 82 of the 200 most typed words in search machines are of pornographic content. There is a high probability that children get confronted with these contents. There are 7650 cesored websites of pedophiles. The number is growing every day. The monetary amount of such pedophilic websites at approximately 5 billion Dollars. According to the report 'Annual Report of Internet Children Abuse', it is mentioned that the internet child abuse is growing faster and that the abused children are under the age of 9. Due to the report, 1.700.000 children abuse and mistreatments videos were gone viral of 36.149 children in the year $2009.42 \%$ of them were under seven years, $77 \%$ of them were under 9 years. Whereas the internet filter and the internet freedom was discussed, the oline children abuse grew up in the last 6 years to $149 \%$ ( Gürhan 2015).

We can classify today's internet sources into areas like: Medicine-Agriculture; Energy and Power - Information and Communication- Transport-Production. The rapid technological development caused big changes in lifestyles. It also affected disloyalty to traditional values. Rapid technological development caused and extended globalisation, new economical management behaviours, e-business, oline-jobs, e-commerces, new client types, social media marketing, etc ( Alkan 2003).

Today's most visible characteristic is the technological lifestyle and the domination of certain powers on the crowd. Technological intruments are very importat but they are also difficult to control. Things like internet, various TV channles, smart phones are changing people to depending ones which cannot decide or think and which have no personal priority nor free behaviour. Technology stands for more than watching and controlling us: it stands for navigating us by building us a new behaviour as well as a life and characteristics. With every instrument we use, we left traces, especially dominant classes can follow us. This causes pathologic humanisations and a healing of personality disorder of those who are watching while those who are watched lose their freedom and this lead them to hopelessness ( Turan S.,Esenoğlu C.,2006) .

\section{CONCLUSION}

As result, if technology is not used in a fairly way, some people will benefit whereas others will suffer. It seems more important that the insistence of technology, no-debating of the importance of the social, moral, political and economical aspects of teachers and schools will lead to the fact that schools loses its meaning. One should not forget that technology leads also to negative aspects like alienation, loneliness, egocentricity. The famous Brazilian philosopher Freire said that 
technology is intead of developing humans more a way of service for the 'oppressors' to make from humans 'objects'. In other words: Technology is a 'culutral invasion' of the ruling class which is against dialogue.

\section{REFERENCES}

Bayatoğlu B.B., ( 2005). Bilişim Teknolojilerinin Türk Bankacılı̆ı̆ın Yönetim Ve Organizasyon Yapısına Etkileri T.C. Pamukkale Üniversitesi Sosyal Bilimler Enstitüsü Iş̧letme Anabilim Dalı Yönetim Ve Organizasyon Bilim Dalı. Yayınlanmamış Yüksek Lisans Tezi

Arun K., Türkay B., Fen G., Vd. ( 2014). Yeni Teknolojilerin Yönetici Rolleri Üzerindeki Etkisini Saptama Üzerine Bir Araştırma . Bjss Balkan Journal Of Social Sciences / Balkan Sosyal Bilimler Dergisi. 3. 6

Yavuz. S., Coşkun.E., ( 2008). Sınıf Öğretmenliği Öğrencilerinin Eğitimde Teknoloji Kullanımına İlişkin Tutum Ve Düşünceleri Attıtudes And Perceptıons Of Elementary Teachıng Through The Use Of Technology In Educatıon . Hacettepe Üniversitesi Eğitim Fakültesi Dergisi (H. U. Journal of Education) 34. ss: 276-286

Turan S., ( 2002). Teknolojinin okul yönetiminde etkin kullanımında eğitim yöneticisinin rolü. Kuram ve uygulamada eğitim yönetimi. 30.ss: 271-81

Çağıltay, K., Çakıroğlu, J., Çağıttay, N. ve Çakıroğlu, E. (2001). Öğretimde Bilgisayar Kullanımına Illişkin Öğretmen Görüşleri. Hacettepe Üniversitesi Eğitim Fakültesi Dergisi,21, 19-28.

Öksüz, C., Ak, Ş. ve Uça, S. (2009). İlköğretim Matematik Öğretiminde Teknoloji Kullanımına iliş̧kin Algı Ölçeği. Yüzüncü Yıl Üniversitesi, Eğitim Fakültesi Dergisi. Haziran 2009. Cilt:V1, Sayı: I, 270-28

Usta, E., Korkmaz, Ö. (2010). Öğretmen adaylarının bilgisayar yeterlikleri ve teknoloji kullanımına ilişkin algıları ile öğretmenlik mesleğine yönelik tutumları. Uluslararası İnsan Bilimleri Dergisi [Bağlantıda]. 7:1. Erişim: http://www.insanbilimleri.com

Karamustafaoğlu O., (2006) . Fen Ve Teknoloji Öğretmenlerinin Öğretim Materyallerini Kullanma Düzeyleri: Amasya İli Örneği . AÜ. Bayburt Eğitim Fakültesi Dergisi. 1. Ss:190-101

Yaşar, O. (2004). İlköğretim Sosyal Bilgiler Derslerinde Görsel Materyal Kullanımı ile Coğrafya Konularının Eğitim ve Öğretimi. Milli Eğitim Dergisi, Sayı: 163,104-120.

Çelen K F., Çelik A ., Seferoğlu S S ( 2011). Türk Eğitim Sistemi ve PISA Sonuçları, Akademik Bilişim. 2-4

Acılar. A., ( 2009). Kobi'lerde Bilişim Teknolojileri Güvenliği Sorunu: Tehditler Ve Önlemler . Afyon Kocatepe Üniversitesi, i.i.i.B.F. Dergisi. C.X I.SI

Turan S., (2002). Teknolojinin Okul Yönetiminde Etkin Kullanımında Eğitim Yöneticisinin Rolü. Kuram Ve Uygulamada Eğitim Yönetimi. 30. 55.ss:271-28

Arıcak, O. T. (2011). Siber zorbalık: Gençlerimizi bekleyen yeni tehlike. Fatih Üniversitesi Kariyer Penceresi Dergisi, 10(6), 11-12

Arı, S. V., Er, S. H., Özer, Ö, ve Şahin, M. (2010). Lise öğrencilerinin siber zorba davranışlarda bulunma ve maruz kalma durumlarında ilişkin görüşleri. SDÜ Dergisi Fen Edebiyat Fakültesi Sosyal Bilimler Dergisi, 21, 257-270.

Alkan N., (2003).Tıp ve Sağlık Kuruluşlarında Yönetim. Bilgi Dünyası. 4.2.ss: 122-145 Turan S.,Esenoğlu C., (2006). Bir Meşrulaştırma Aracı Olarak Bilişim ve Kitle İletişim Teknolojileri: Eleştirel Bir Bakış. Eskişehir Osmangazi Üniversitesi. İiBF Dergisi. 1.2.ss: 71-86 